\title{
Diketocamphane enantiomer-specific 'Baeyer-Villiger' monooxygenases from camphor-grown Pseudomonas putida ATCC 17453
}

\author{
Kerina H. Jones, Roy T. Smith and Peter W. Trudgill* \\ Department of Biochemistry, University of Wales, Aberystwyth SY23 3DD, UK
}

(Received 13 July 1992; revised 25 November 1992; accepted 21 December 1992)

\begin{abstract}
Pseudomonas putida ATCC 17453 grew with either (+)- or (-)-camphor as sole carbon source. Enantiomerspecific 'biological Baeyer-Villiger' monooxygenases were synthesized irrespective of the camphor isomer used for growth. The two enzymes are probably the products of separate genes but showed many similarities. Each consisted of two electrophoretically indentical subunits, bound flavin mononucleotide (FMN) non-covalently and accepted electrons from an induced NADH dehydrogenase which interacted with the FMN bound to the oxygenating component. They showed minor differences in $M_{\mathrm{r}}$ with 3,6-diketocamphane 1,6-monooxygenase being the smaller enzyme. Isoelectric focussing showed the two enzymes to have different acidic pI values. Polyclonal antibodies raised against 3,6-diketocamphane 1,6-monooxygenase also cross-reacted with 2,5-diketocamphane 1,2-monooxygenase and its subunits.
\end{abstract}

\section{Introduction}

Camphor exists in two enantiomeric forms; the (+)isomer occurs primarily in the wood of Cinnanocum camphora and, although the (-)-isomer is less widely distributed it occurs in a number of plant essential oils. The racemate also occurs naturally and is found in the essential oil of Crysanthemum sinense (Pelter \& Harper, 1969). Pseudomonas putida ATCC 17453 will grow with either isomer of camphor as sole source of carbon (LeGall et al., 1963). Although numerous papers and reviews have been written concerning the metabolism of (+)-camphor by $P$. putida ATCC 17453 knowledge concerning the pathways and enzymology of (+)- and (-)-camphor oxidation is incomplete. Reactions leading to cleavage of both carbocyclic rings of the bicyclic monoterpene have been elucidated for the degradation of (+)-camphor (Conrad et al., 1961, 1965a, b; Ougham et $a l ., 1983)$ and the metabolism of $(-)$-camphor has been shown to proceed through a parallel enantiomeric sequence of intermediates, that were transiently accumulated in culture medium (Chapman et al., 1964; Gunsalus \& Marshall, 1971). The established reaction sequences are shown in Fig. 1. The genes that code for these catabolic enzymes are carried on the $165 \mathrm{MDa}$

\footnotetext{
*Author for correspondence. Tel. 0970 622299; fax 0970622307.

Abbreviations: FAD, flavin adenine dinucleotide; FMN, flavin mononucleotide; FPLC, fast protein liquid chromatography.
}

transmissible CAM plasmid (Rheinwald et al., 1973; Palchaudhuri \& Chakrabarty, 1976; Ougham et al., 1983). Isobutyrate has been implicated as a common catabolic intermediate close to central metabolism and the genes that code for isobutyrate metabolism and essential anaplerotic and amphibolic pathways are chromosomal (Rheinwald et al., 1973).

The established enzymology of ring cleavage has some interesting complications. The initial monooxygenase, a cytochrome-P450-containing enzyme complex, is induced by growth with either isomer of camphor (Gunsalus \& Marshall, 1971). It forms 5-exo-hydroxycamphor from $(+)$-camphor and hydroxylates $(-)$-camphor in the corresponding enantiomeric position. Two discrete hydroxycamphor dehydrogenases have been reported, each with a preference for the hydroxycamphor derived from the camphor isomer used for growth but neither showing absolute specificity (Gunsalus \& Marshall, 1971). Ring oxygen insertion into 2,5-diketocamphane, formed from (+)-camphor, is catalysed by a 1,2monooxygenase that is a very loose complex of two proteins, an NADH dehydrogenase and a flavin mononucleotide (FMN)-containing oxygenating component. Both proteins of this biological 'Baeyer-Villiger' oxygenase have been purified to homogeneity (Trudgill et al., 1966; Taylor \& Trudgill, 1986). In complete contrast to the hydroxylase and the two dehydrogenases, this oxygenase is absolutely specific for (+)-camphor and substituted $(+)$-camphor derivatives, such as 2,5 diketocamphane. It is inactive with (-)-camphor and 
<smiles>CC12CCC(CCC1=O)C2(C)C</smiles><smiles>CC12CCC(CCC1=O)C2(C)C</smiles><smiles>[3H]I</smiles><smiles>CC1(C)CC2CC(=O)CC1C2(C)C</smiles><smiles>CC12CC(=O)CC([C@H](O)C1)C2(C)C</smiles>
$\downarrow 2 a, b\rfloor$<smiles>CC1(C)CC2CC(=O)C1CC2=O</smiles><smiles>CC1(C)C2CC(=O)CC1C(=O)C2</smiles>
3<smiles>CCOC1(C)CC(=O)CC2CC(=O)CC1(C)C2(C)C</smiles>

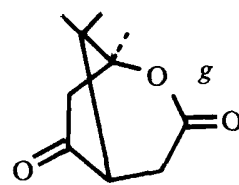

Fig. 1. Early reactions in the catabolism of camphor isomers by Pseudomonas putida ATCC 17453. Compounds are: $a$, (+)-camphor; $b$, 5-exo-hydroxycamphor; $c, 2,5$-diketocamphane; $d,(-)$-camphor; $e$, 3,6-diketocamphane; $f$ and $g$, enantiomeric unstable lactones produced by oxygenation of the diketocamphanes. Enzymes are: 1, camphor exohydroxylase ; $2 a, 2 b$, exo-hydroxycamphor dehydrogenases; 3, 2,5diketocamphane 1,2-monooxygenase; 4, 3,6-diketocamphane 1,6monooxygenase (the monooxygenases are also able to oxygenate the respective camphor isomers).

other ketocamphanes that do not possess a keto group at the 2-position.

It had been assumed, on the basis of the ability of the organism to grow with (-)-camphor, the spectrum of accumulated metabolites, the specificity of the 2,5diketocamphane 1,2-monooxygenase and from genetic studies in which mutants, unable to grow with $(+)$ camphor but able to grow with (-)-camphor and the enantiomer of 2-oxo- $\Delta^{3}-4,5,5$-trimethylcyclopentenylacetic acid derived from (+)-camphor, that an isofunctional enzyme specific for (-)-camphor and 3,6diketocamphane is also synthesized by the organism (LeGall et al., 1963; Gunsalus \& Marshall, 1971; Rheinwald et al., 1973). In this paper we report the purification and characterization of this enatiomeric 'Baeyer-Villiger' monooxygenase and compare it with 2,5-diketocamphane 1,2-monooxygenase.

\section{Methods}

Bacterial strains. Pseudomonas putida C1B (ATCC 17453) was obtained from the American Type Culture Collection, Rockville, MD, USA, maintained on nutrient agar slopes at $4{ }^{\circ} \mathrm{C}$ and subcultured at monthly intervals.

Growth conditions. Cultures were grown aerobically at $30^{\circ} \mathrm{C}$. Basal media contained $\left(\mathrm{g} \mathrm{l}^{-1}\right): \mathrm{KH}_{2} \mathrm{PO}_{4}, 2 ; \mathrm{Na}_{2} \mathrm{HPO}_{4}, 4 ;\left(\mathrm{NH}_{4}\right)_{2} \mathrm{SO}_{4}, 1$; and $4 \mathrm{ml}$ trace metal stock solution (Rosenberger \& Elsden, 1960). Camphor was added at $2.5 \mathrm{~g} \mathrm{l}^{-1}$ before autoclaving. Some loss of camphor occurred during autoclaving and the resulting saturated medium contained approximately $1.5 \mathrm{~g}^{-1}$. Cultures were usually grown according to the following procedure: $20 \mathrm{ml}$ of medium in a $100 \mathrm{ml}$ conical flask was inoculated from a slope and grown on an orbital shaker (150 r.p.m.) for 24 h. Subsequently, $10 \%$ inocula were transferred sequentially to $50 \mathrm{ml}$ and $500 \mathrm{ml}$ volumes of media, in $250 \mathrm{ml}$ and $2 \mathrm{l}$ conical flasks, respectively, at $12 \mathrm{~h}$ intervals. Two $500 \mathrm{ml}$ cultures were used to inoculate 101 of medium in a New Brunswick Microferm laboratory fermenter which was stirred at 400 r.p.m and aerated with sterile air at a rate of $31 \mathrm{~min}^{-1}$. Growth was monitored at $580 \mathrm{~nm}$ and further additions of camphor $\left(0.5 \mathrm{~g} \mathrm{l}^{-1}\right)$ made at readings of approximately $1 \cdot 6$ and $2 \cdot 0$. Cells were harvested by continuous flow centrifugation when the $\mathrm{OD}_{580}$ reading reached approximately $2 \cdot 5$. For growth with (+)-camphor as carbon source larger batches of cells were obtained by using the 111 fermenter culture to inoculate 301 of nonsterile medium in a 50-plastic vessel which was stirred at 700 r.p.m. and aerated with sterile air at a rate of $71 \mathrm{~min}^{-1}$. Growth was monitored at $580 \mathrm{~nm}$ and further additions of $(+)$-camphor $\left(1 \mathrm{~g} \mathrm{l}^{-1}\right)$ were made at readings of 3.0 and $4 \cdot 0$. Cells were harvested when the optical density value exceeded 5.5 and while the cultures were still in the exponential phase of growth, typically after $5 \mathrm{~h}$. Cell pastes were resuspended in an equal volume of $42 \mathrm{~mm}$-phosphate buffer $(\mathrm{pH} 7 \cdot 1)$ and stored at $-20^{\circ} \mathrm{C}$ until required.

Preparation of cell extracts. Cell suspensions were thawed at room temperature and disrupted by ultrasonic disintegration at $23 \mathrm{KHz}$ with a probe amplitude of $18 \mu \mathrm{m}$ (MSE Soniprep 150). Each $100 \mathrm{ml}$ portion was disrupted for eight $30 \mathrm{~s}$ periods, interspersed with $60 \mathrm{~s}$ of cooling on ice. Broken cell suspensions were centrifuged $\left(48000 \mathrm{~g}, 3^{\circ} \mathrm{C}\right.$, $45 \mathrm{~min}$ ). The protein content of extracts was measured by the method of Gornall et al. (1949) and they were stored at $-20^{\circ} \mathrm{C}$ until required.

Buffers. The $42 \mathrm{~mm}$-sodium/potassium phosphate buffer used routinely was prepared by dissolving $4 \mathrm{~g} \mathrm{Na}_{2} \mathrm{HPO}_{4}$ and $2 \mathrm{~g} \mathrm{KH}_{2} \mathrm{PO}_{4}$ in 11 distilled water, giving a $\mathrm{pH}$ of $7 \cdot 1$. Phosphate buffers of different molarities were made by diluting this buffer as required. Other buffers were made by adjustment of a solution of the appropriate compound to the required $\mathrm{pH}$ with $1 \mathrm{M}-\mathrm{NaOH}$ or $1 \mathrm{M}-\mathrm{HCl}$ and diluting to the required concentration.

Enzyme assays. NADH dehydrogenase was assayed by following the rate of $\mathrm{NADH}$ oxidation when the enzyme fraction, containing $0.02-0.2 \mathrm{U}$ of enzyme, was added to a $1 \mathrm{~cm}$ light-path cuvette that contained, in a final volume of $1 \mathrm{ml} ; 0 \cdot 15 \mu \mathrm{mol} \mathrm{NADH}, 25 \mathrm{nmol}$ FMN and $40 \mu \mathrm{mol}$ phosphate buffer (pH 7:1).

Diketocamphane monooxygenase activities were routinely assayed either by measuring substrate-stimulated NADH oxidation spectrophotometrically or by measuring oxygen consumption polarographically. A typical reaction system contained, in a total volume of $3 \mathrm{ml}: 0.5 \mu \mathrm{mol} \mathrm{NADH}, 120 \mu \mathrm{mol}$ phosphate buffer $(\mathrm{pH} 7.1)$ and $0.025-0.25 \mathrm{U}$ of oxygenase activity. After the endogenous rate was measured the reaction was started by the addition of $1 \mu \mathrm{mol}(+)-$ or $(-)$-camphor as appropriate. Purification of the oxygenase proteins yielded preparations that were progressively deficient in the NADH dehydrogenase component and, occasionally, in FMN and it was necessary to add these components to the standard assays. As the 
quantities required varied with the degree of purification and assay situation they are indicated at the appropriate points in the text.

Enzyme units. One enzyme unit $(\mathrm{U})$ is defined as the consumption of $1 \mu \mathrm{mol}$ of substrate or the formation of $1 \mu \mathrm{mol}$ product $\mathrm{min}^{-1}$. All assays were done at $30^{\circ} \mathrm{C}$.

Protein measurement. The protein content of crude cell extracts was routinely measured by the modified biuret method of Gornall et al. (1949). A crude estimate of the protein content of column fractions was made by measuring $A_{280}$. For accurate measurement of the protein content of pooled column fractions and purified enzymes the modified biuret assay or the tannin-gum-arabic turbidometric assay (MejbaumKatzenellenbogen \& Dobryszycka (1959) was used, depending upon the amount of material available.

Enzyme purification. The soluble NADH dehydrogenase was purified from (+)-camphor-grown P. putida ATCC 17453 according to the procedure of Trudgill et al. (1966) and had a specific activity of $300 \mathrm{U}$ (mg protein $)^{-1}$.

3,6-Diketocamphane 1,6-monooxygenase was purified from (-)camphor-grown cells by a modification of the procedure described previously (Taylor \& Trudgill, 1986) for the purification of 2,5diketocamphane monooxygenase. The only significant modification was the substitution of fast protein liquid chromatography (FPLC) on a Hiload 16/10 Q Sepharose column for the Polyanion 17 column used previously. All procedures, with the exception of FPLC, were carried out at $4{ }^{\circ} \mathrm{C}$.

Step 1. Cell extract, prepared from approximately $65 \mathrm{~g}$ of $(-)$ camphor-grown cells, was treated with saturated $\left(\mathrm{NH}_{4}\right)_{2} \mathrm{SO}_{4}$ to bring it to $50 \%$ saturation. After stirring at $4{ }^{\circ} \mathrm{C}$ for $30 \mathrm{~min}$ the precipitate was removed by centrifuging at $27000 \mathrm{~g}$ and the pellet discarded. The clear yellow supernatant was then brought to $75 \%$ saturation by addition of solid $\left(\mathrm{NH}_{4}\right)_{2} \mathrm{SO}_{4}$ and again stirred and centrifuged. The pellet was dissolved in $150 \mathrm{ml} 21 \mathrm{~mm}$-phosphate buffer $(\mathrm{pH} \mathrm{7 \cdot 1)}$ and dialysed overnight against two changes (5l each) of the same buffer.

Step 2. The dialysed solution was applied to a DEAE-cellulose column $(11 \times 2.5 \mathrm{~cm})$ equilibrated with the same buffer. The column was washed with 4 column volumes of buffer and then developed by passage of a linear $\mathrm{KCl}$ gradient $(300 \mathrm{ml}, 0-0 \cdot 4 \mathrm{M}-\mathrm{KCl}$ in phosphate buffer). The flow rate was $1 \mathrm{ml} \mathrm{min}{ }^{-1}$ and 3-4 ml fractions were collected. Diketocamphane oxygenase-containing fractions were pooled as appropriate and dialysed against two changes (21 each) of $50 \mathrm{~mm}$-Tris/HCl buffer $(\mathrm{pH} \mathrm{7.7)}$ for a total of $7 \mathrm{~h}$.

Step 3. FPLC was carried out on a Hiload 16/10 Q Sepharose column (Pharmacia Biosystems). Sequential chromatographic runs were performed in which the column load did not exceed $20 \mathrm{mg}$ protein. Enzymes were eluted from the column by the passage of a linear $\mathrm{KCl}$ gradient $(250 \mathrm{ml}, 0-0.5 \mathrm{M}-\mathrm{KCl}$ in the Tris/ $\mathrm{HCl}$ buffer $)$ and $3 \mathrm{ml}$ fractions collected. Fractions containing enzyme were pooled and stored at $-20^{\circ} \mathrm{C}$ until required.

2,5-Diketocamphane 1,2-monooxygenase from (+)-camphor-grown $P$. putida ATCC 17453 was purified using the same sequence of steps, scaled up to process the volume of extract obtained from $250 \mathrm{~g}$ of cells

$P A G E$. This was done under non-denaturing conditions on $1.5 \mathrm{~mm}-$ thick 6,10 or $12.5 \%(\mathrm{w} / \mathrm{v})$ polyacrylamide minigels $(80 \times 60 \mathrm{~mm})$ according to the procedure of Davies (1964). SDS slab gel electrophoresis was done according to the procedure of Laemmli (1970) on $11,12.5$ and $15 \%(\mathrm{w} / \mathrm{v})$ gels. Gels were stained with $0.2 \%(\mathrm{w} / \mathrm{v})$ Coomassie brilliant blue R250 in ethanol/water/glacial acetic acid (9:9:2 by vol.) for at least $1 \mathrm{~h}$ and destained in water/ethanol/glacial acetic acid (13:5:2 by vol.).

Isoelectric focussing. Isoelectric focussing was carried out on $2 \mathrm{~mm}$ thick polyacrylamide gels over a $\mathrm{pH}$ range from 3 to 9 in an LKB Multiphor 2117 electrophoresis unit essentially as described by Vesterberg (1972). Myoglobin was used as a marker protein. After focussing gels were fixed and washed in methanol/glacial acetic acid/water $(5: 1: 4$ by vol.) and stained with Coomassie brilliant blue R250

$M_{r}$ determination. The $M_{\mathrm{r}}$ value of native 3,6-diketocamphane 1,6monooxygenase was determined in the ultracentrifuge by the method of Yphantis (1964). A double sector cell was used with the enzyme solution in one compartment and the diffusate, $42 \mathrm{~mm}$-phosphate buffer ( $\mathrm{pH} \mathrm{7.1)} \mathrm{in} \mathrm{the} \mathrm{other.} \mathrm{The} \mathrm{rotor} \mathrm{speed} \mathrm{was} 21740$ r.p.m. and the initial protein concentration $0.5 \mathrm{mg} \mathrm{m}^{-1}$. The enzyme was stable for the duration of the experiment.

GLC. A Carol-Erba HRGC 5300 Mega series instrument fitted with an SE-34 column $(0.32 \mathrm{~mm} \times 30 \mathrm{~m})$ with a film thickness of $0.25 \mathrm{~mm}$ (Alltech) was used. Carrier gas flow rate was $1.5 \mathrm{ml} \mathrm{min}^{-1}$ and the temperature programme $45-80^{\circ} \mathrm{C}$ at $4{ }^{\circ} \mathrm{C} \mathrm{min}-1 ; 80-150^{\circ} \mathrm{C}$ at $25^{\circ} \mathrm{C}$ $\min ^{-1}$ and $150-200^{\circ} \mathrm{C}$ at the maximum rate (approx. $30^{\circ} \mathrm{C} \mathrm{min}{ }^{-1}$ ).

Oxygen uptake measurement. $\mathrm{O}_{2}$ consumption by cell suspensions or by cell extracts was determined by conventional Warburg manometry or with a Clark-type $\mathrm{O}_{2}$ electrode in an agitated vessel maintained at $30^{\circ} \mathrm{C}$ (Yellow Springs Instrument Co.).

Preparation of antibodies. A total of $150 \mu \mathrm{g}$ of electrophoretically homogeneous 3,6-diketocamphane 1,6-monooxygenase from $P$. putida ATCC 17453, emulsified in Freund's complete adjuvant was injected subcutaneously at multiple sites into an adult female rabbit, followed by a similar injection in Freund's incomplete adjuvant after 3 weeks. A trial bleed of the animal was performed 2 weeks after the second injection and the full bleed 1 week later. The IgG fraction of the antiserum was partially purified by acidification ( $\mathrm{pH} 4.5$ ), ammonium sulphate precipitation and heat treatment $\left(50^{\circ} \mathrm{C}\right)$ according to the procedure of McKinney \& Parkinson (1987). A sample of pre-immune serum was taken from the rabbit before immunization.

ELISA. ELISA were done on microtitre well plates with alkaline phosphatase-labelled goat anti-rabbit immunoglobulin (Bio-Rad) and $p$-nitrophenyl phosphate as substrate. Reactions were stopped by the addition of $50 \mu \mathrm{l} 3 \mathrm{M}-\mathrm{NaOH}$. $A_{405}$ values were read on a Bio-Rad model 2550 plate reader.

Immunodiffusion. Ouchterlony double immunodiffusion analysis was done in $3 \mathrm{~mm}$-thick gels made from PBS $\left(1^{-1}: 8 \mathrm{~g} \mathrm{NaCl}, 0 \cdot 2 \mathrm{~g} \mathrm{KCl}\right.$, $1 \cdot 15 \mathrm{~g} \mathrm{Na}_{2} \mathrm{HPO}_{4}, 0.2 \mathrm{~g} \mathrm{KH}_{2} \mathrm{PO}_{4}$ ) solidified with $1.5 \%(\mathrm{w} / \mathrm{v})$ purified agar. Centre wells were typically filled with $30 \mu \mathrm{l}$ of control serum, test serum or purified antiserum and 10-25 $\mu \mathrm{g}$ of antigenic protein in $30 \mu \mathrm{l}$ of solution placed in the outer wells. After $18 \mathrm{~h}$ incubation at $20^{\circ} \mathrm{C}$, plates were visually examined for precipitin lines.

Immunoblotting (Western blotting). After separation by SDS-PAGE the proteins were electrophoretically transferred at a constant voltage of $100 \mathrm{~V}$ for $60 \mathrm{~min}$ from the polyacrylamide gel onto a nitrocellulose sheet in a Bio-Rad Trans Blot electrophoretic transfer cell. Blotting buffer was composed of $25 \mathrm{~mm}$-Tris, $192 \mathrm{~mm}$-glycine and $20 \%(\mathrm{v} / \mathrm{v})$ methanol, $\mathrm{pH} 8 \cdot 3$.

Rabbit antibodies against 3,6-diketocamphane 1,6-monooxygenase were used for antigen detection. After incubation overnight at $4{ }^{\circ} \mathrm{C}$ in PBS containing $3 \%$ bovine serum albumin, the nitrocellulose sheet was washed in PBS, then incubated for $1 \mathrm{~h}$ at room temperature with rabbit antibody solution diluted $2 \times 10^{3}$-fold. The sheet was again washed in PBS, incubated with goat anti-rabbit IgG conjugated to alkaline phosphatase (Bio-Rad) diluted $2 \times 10^{3}$-fold in PBS for $1 \mathrm{~h}$, washed again and developed with 5-bromo-4-chloro-3-indolyl phosphate/nitroblue tetrazolium reagent (Bio-Rad).

Chemicals. (+)-Camphor, (-)-camphor ( 95 and $99 \%$ purity) were obtained from Sigma; DEAE-cellulose (DE-52) from Whatman and other chemicals were generally Analar grade from Merck. Gas chromatographic analysis of the $95 \%(-)$-camphor confirmed that, as 
reported by the manufacturers, the impurity was fenchone. Goat antirabbit IgG $(\mathrm{H}+\mathrm{L})$ alkaline phosphatase conjugate and the substrate kit were obtained from Bio-Rad.

\section{Results}

Pseudomonas putida ATCC 17453 was capable of growth with either isomer of camphor as sole source of carbon. Growth rates and growth yields showed no significant differences. The oxidation of camphor was inducible and, irrespective of the isomeric configuration of the camphor used for growth, both isomers of camphor were oxidized rapidly without an initial lag phase. Addition of chloramphenicol $\left(50 \mu \mathrm{g} \mathrm{ml}^{-1}\right)$ had no effect upon this oxidation pattern.

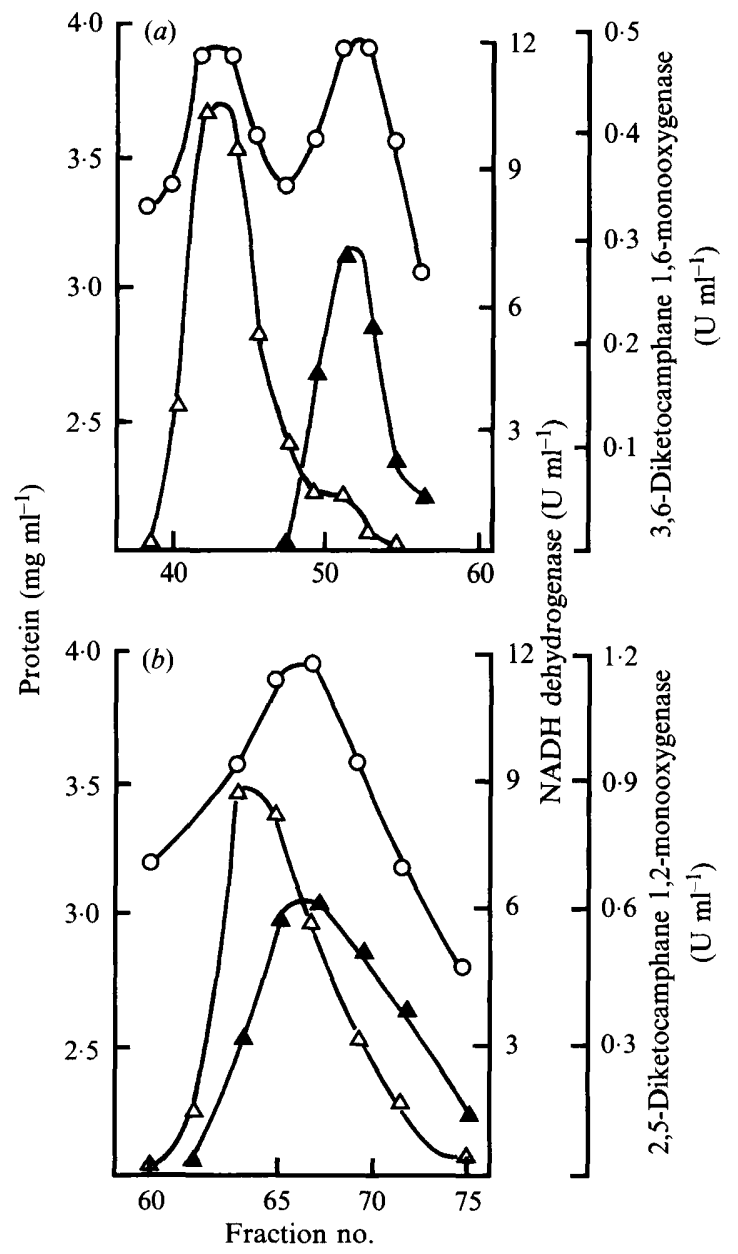

Fig. 2. Chromatography of NADH dehydrogenase $(\triangle)$, and (a) 3,6diketocamphane 1,6-monooxygenase $(\boldsymbol{\Delta})$ and $(b)$ 2,5-diketocamphane 1,2-monooxygenase (A) on DEAE-cellulose. (a). Protein $(O)$ from the $\left(\mathrm{NH}_{4}\right)_{2} \mathrm{SO}_{4}$ fractionation $(1200 \mathrm{mg})$ was loaded onto a $2.5 \times 10 \mathrm{~cm}$ DEAE-cellulose column which was then developed as described in Methods and $3.8 \mathrm{ml}$ fractions were collected. $(b)$. Protein $(O)$ from the $\left(\mathrm{NH}_{4}\right)_{2} \mathrm{SO}_{4}$ fractionation $(4700 \mathrm{mg})$ was loaded onto a $5 \times 10 \mathrm{~cm}$ DEAEcellulose column which was then developed as described in Methods and $10 \mathrm{ml}$ fractions were collected. Gradient sizes were adjusted to be directly proportional to the column bed volumes.

\section{Enzyme assays}

Difficulties attended the assay of the NADH-linked 2,5diketocamphane 1,2-monooxygenase from $P$. putida ATCC 17453. The enzyme is a loose complex of two proteins with a dissociation constant of approx $50 \mathrm{~nm}$ (Taylor \& Trudgill, 1986) and it is not possible to perform spectrophotometric assays with crude cell extract because of the presence of soluble NADH oxidases and free flavins that compete for NADH. Spectrophotometric assays can be employed subsequent to $\left(\mathrm{NH}_{4}\right)_{2} \mathrm{SO}_{4}$ fractionation. As purification of the oxygenating component progresses it becomes NADH dehydrogenase-depleted and it is necessary to add NADH dehydrogenase to display activity of fractions containing the oxygenase. In the absence of information to the contrary the assumption that a similar situation would appertain to oxygenation of (-)-camphor (and 3,6-diketocamphane) was suggested by the knowledge that a high level of the soluble NADH dehydrogenase was also induced by growth on (-)-camphor (Gunsalus et al., 1965). This proved to be a useful starting point. Availability of substrates also presented a problem. 2,5Diketocamphane 1,2-monooxygenase is also active towards (+)-camphor as a substrate (Conrad et al. 1965; Taylor \& Trudgill, 1986) but is inactive towards (-)camphor. The enzyme may be conveniently assayed with $(+)$-camphor which has the advantage of ensuring that the biological Baeyer-Villiger oxygenase is not confused with the NAD-linked 5-hydroxycamphor dehydrogenases. 3,6-Diketocamphane was not available to us and, since it has been reported that, in relatively crude protein preparations, (-)-camphor serves as a substrate for biological Baeyer-Villiger oxygenation (Gunsalus et al., 1965), this terpene ketone was used as a substrate in the search for the enantiomer-specific oxygenase.

\section{Purification of 3,6-diketocamphane 1,6-monooxygenase and 2,5-diketocamphane 1,2 monooxygenase}

Preliminary purification trials with the 3,6-diketocamphane 1,6-monooxygenase exploited the regime already established for 2,5-diketocamphane 1,2-monooxygenase purification from (+)-camphor-grown $P$. putida (Taylor \& Trudgill, 1986). $\left(\mathrm{NH}_{4}\right)_{2} \mathrm{SO}_{4}$ fractionation showed that, as with 2,5-diketocamphane 1,2monooxygenase, an NADH-dependent oxygenase, active with (-)-camphor, was selectively precipitated in the $50-75 \%$ saturation fraction. In contrast, DEAE-cellulose chromatography yielded fractions with low oxygenase activity when (-)-camphor was used as substrate in the absence of added NADH dehydrogenase. As with the purification of 2,5-diketocamphane 1,2-monooxygenase from (+)-camphor-grown cells, some of the soluble NADH dehydrogenase carried over into the 
Table 1. Purification of 2,5- and 3,6-diketocamphane monooxygenases from

$$
\text { P. putida ATCC } 17453
$$

Fractions were assayed for monooxygenase activity with $(+)$ - or $(-)$-camphor as substrate, as appropriate. Typically $0.15-0.4 \mathrm{U}$ NADH dehydrogenase was added to fractions deficient in this enzyme and FMN was supplied at 5-10 $\mu \mathrm{M}$ to assays of fractions from FPLC columns. (a), 3,6-Diketocamphane monooxygenase from extract of (-)-camphor-grown cells; $(b), 2,5-$ diketocamphane monooxygenase from extract of $(+)$-camphor-grown cells.

\begin{tabular}{|c|c|c|c|c|c|}
\hline Stage & $\begin{array}{l}\text { Total protein } \\
(\mathrm{mg})\end{array}$ & $\begin{array}{l}\text { Total activity* } \\
\text { (U) }\end{array}$ & $\begin{array}{l}\text { Specific activity*† } \\
{\left[\mathrm{U}(\mathrm{mg} \text { protein })^{-1}\right]}\end{array}$ & $\begin{array}{c}\text { Yield } \dagger \\
(\%)\end{array}$ & $\begin{array}{l}\text { Purification } \\
\text { (-fold) }\end{array}$ \\
\hline \multicolumn{6}{|l|}{ (a) } \\
\hline Crude extract & 8664 & ND & ND & ND & - \\
\hline $\begin{array}{l}\left(\mathrm{NH}_{4}\right)_{2} \mathrm{SO}_{4} \\
\text { fractionation }\end{array}$ & 1260 & $17 \cdot 8$ & 0.014 & 100 & 1 \\
\hline $\begin{array}{l}\text { DEAE-cellulose } \\
\text { chromatography }\end{array}$ & 73 & $4 \cdot 5$ & 0.062 & $25 \cdot 3$ & $4 \cdot 4$ \\
\hline Q Sepharose & 16 & $3 \cdot 9$ & $0 \cdot 244$ & $21 \cdot 9$ & $17 \cdot 4$ \\
\hline \multicolumn{6}{|l|}{ (b) } \\
\hline Crude extract & 30228 & ND & ND & ND & - \\
\hline $\begin{array}{l}\left(\mathrm{NH}_{4}\right)_{2} \mathrm{SO}_{4} \\
\text { fractionation }\end{array}$ & 4762 & 84 & $0 \cdot 018$ & 100 & 1 \\
\hline $\begin{array}{l}\text { DEAE-cellulose } \\
\text { chromatography }\end{array}$ & 133 & 22 & $0 \cdot 165$ & $26 \cdot 2$ & $9 \cdot 2$ \\
\hline Q-Sepharose & 49 & $16 \cdot 4$ & $0 \cdot 335$ & $19 \cdot 5$ & $18 \cdot 6$ \\
\hline
\end{tabular}

ND, Not determined, see Methods.

* Not the maximum activity, not extrapolated to $\infty$ protein concentrations.

$\dagger\left(\mathrm{NH}_{4}\right)_{2} \mathrm{SO}_{4}$ fraction used as $100 \%$ yield and specific activity reference point.

$50-75 \%$ saturation fraction and was eluted as a distinct fraction on the DEAE-cellulose column. However, when NADH dehydrogenase $(0.4 \mathrm{U})$, purified from the $0-50 \%$ saturation $\left(\mathrm{NH}_{4}\right)_{2} \mathrm{SO}_{4}$ fraction from extract of $(+)$ camphor-grown cells, according to the procedure of Trudgill et al. (1966), was added to assays, fractions with activity towards (-)-camphor were revealed (Fig. $2 a$ ).

A clear distinction between this enzyme and 2,5diketocamphane 1,2-monooxygenase was immediately apparent, since the oxygenase and residual NADH dehydrogenase were separated from each other with only a margin of overlap. In contrast, chromatography of a $50-75 \%\left(\mathrm{NH}_{4}\right)_{2} \mathrm{SO}_{4}$ saturation protein fraction from (+)-camphor-grown cells on DEAE-cellulose under closely similar conditions always resulted in significant overlap of the NADH dehydrogenase and 2,5-diketocamphane oxygenase peaks so that, although this oxygenating complex was not fully assembled, significant activity was observed (Fig. $2 b$ ).

Purification of 3,6-diketocamphane 1,6-monooxygenase was completed by FPLC on a Q-Sepharose column (Pharmacia-LKB). This step introduced an additional complication by stripping flavin from the enzyme and, in addition to purified NADH dehydrogenase, FMN had also to be added to assays for oxygenase activity to be revealed [flavin-adenine dinucleotide (FAD) was ineffective]. The 2,5-diketocamphane 1,2-monooxygenase from (+)-camphor-grown cells was eluted at a different position on the gradient and it also lost its flavin component which is known to be FMN (Taylor \& Trudgill, 1986) on this particular column.

Preliminary native PAGE analysis revealed that the 2,5-diketocamphane 1,2-monooxygenase still contained some impurities and a portion of it was therefore subjected to a clean-up step by FPLC on a Superose 12 HR 10/30 column (Pharmacia-LKB) for use in immunological studies. Table 1 shows typical purification results for the two enzymes.

Product of oxygenation of (-)-camphor by 3,6diketocamphane monooxygenase

Previous proposals that $(+)$ - and (-)-camphor are metabolized by converging enantiomeric reaction sequences were supported by the isolation of the same hydroxycamphor and diketocamphane intermediates, in their respective enantiomeric forms from cultures growing on the respective camphor isomers (Gunsalus \& Marshall, 1971). Purified 3,6-diketocamphane monooxygenase $(0.2 \mathrm{U})$ was incubated with $3 \mu \mathrm{mol}(-)$ camphor in the presence of $750 \mathrm{nmol} \mathrm{NADH}, 7.5 \mathrm{nmol}$ FMN and 1.2 U NADH dehydrogenase [purified from (+)-camphor grown $P$. putida] in phosphate buffer, $\mathrm{pH} 7 \cdot 1$, for $8 \mathrm{~min}$ at $30^{\circ} \mathrm{C}$. The product was extracted with diethyl ether and analysed by GLC. Because of the inclusion of excess camphor a significant portion remained at the end of the reaction (retention time 


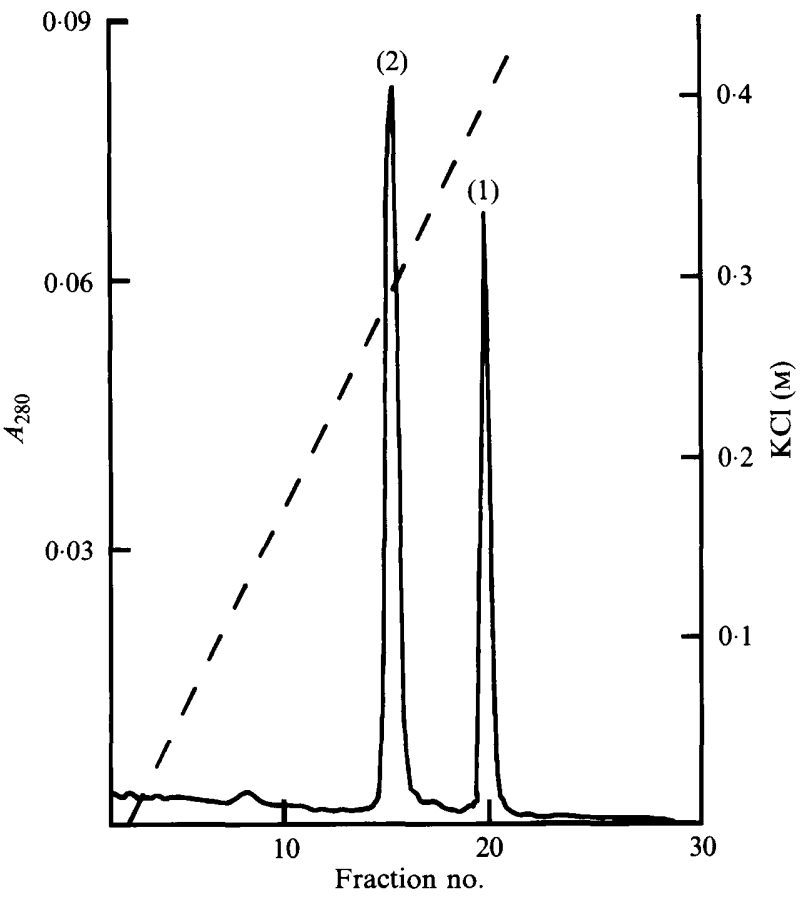

Fig. 3. Analysis of a mixture of (1) 3,6-diketocamphane 1,6monooxygenase $(24 \mu \mathrm{g})$ and (2) 2,5-diketocamphane 1,2-monooxygenase $(52 \mu \mathrm{g})$ by FPLC on a Mono Q column. Enzymes were eluted by the passage of a linear gradient from 0 to $0.5 \mathrm{M}-\mathrm{KCl}$ in $50 \mathrm{mM}$ Tris/HCl buffer (--) through the column. Flow rate, $1 \mathrm{ml} \mathrm{min}^{-1}$; fraction size, $1 \mathrm{ml}$.

10.92 $\mathrm{min}$ ) to act as an internal marker for the reaction product (retention time $19.04 \mathrm{~min}$ ), giving relative retention times of $1: 1 \cdot 74$. When an identical experiment was done with (+)-camphor and the 2,5-diketocamphane 1,2-monooxygenase the (+)-camphor had a retention time of $10.86 \mathrm{~min}$ and the reaction product, $18.98 \mathrm{~min}$, giving relative retention times of $1: 1.75$. This confirmed that the oxygenase purified from (-)-camphor grown cells was indeed the 3,6-diketocamphane 1,6-monooxygenase proposed previously (Gunsalus \& Marshall, 1971).

\section{Properties of 3,6-diketocamphane 1,6-monooxygenase and comparison with 2,5-diketocamphane 1,2- monooxygenase}

\section{(i) Analytical FPLC}

The pure 3,6-diketocamphane 1,6-monooxygenase was subjected to FPLC on a Mono Q column and eluted as a sharp, symmetrical protein peak quite distinct from the 2,5-diketocamphane 1,2-monooxygenase, clearly showing the two enzymes to be discrete proteins (Fig. 3).

\section{(ii) PAGE}

Native PAGE of the 3,6-diketocamphane 1,6-monooxygenase gave a single protein band that migrated

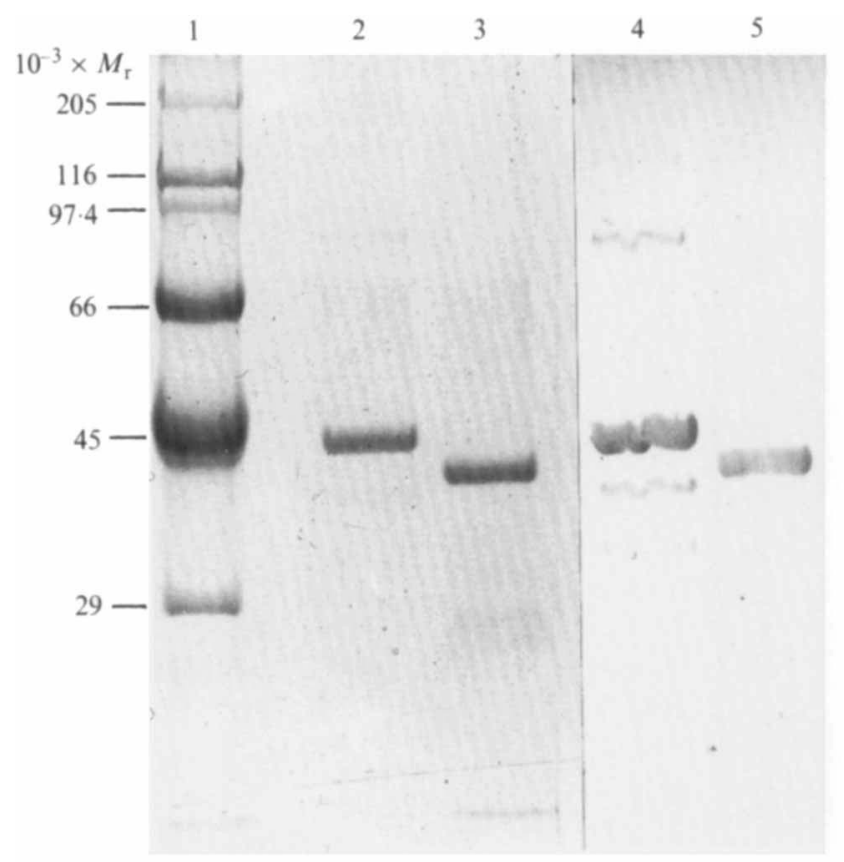

Fig. 4. A montage of SDS-PAGE and Western blotting of purified subunits of 3,6-diketocamphane 1,6-monooxygenase and 2,5-diketocamphane 1,2-monooxygenase separated on a $12.5 \%$ polyacrylamide gel according to the procedure of Laemmli (1970). Lanes: 1, $M_{\mathrm{r}}$ (29000-205000; Sigma); 2, 2,5-diketocamphane monooxygenase $(7 \mu \mathrm{g}) ; 3$, 3,6-diketocamphane 1,6-monooxygenase $(7 \mu \mathrm{g})$ all stained with Coomassie brilliant blue; 4 , Western blot of 2,5-diketocamphane 1,2-monooxygenase subunit probed with a 1:2000 dilution of partially purified antibody raised to 3,6-diketocamphane 1,6-monooxygenase; 5 , Western blot of 3,6-diketocamphane 1,6-monooxygenase probed with the same antibody preparation. Blots were developed with a 1:2000 dilution of goat anti-rabbit IgG, conjugated to alkaline phosphatase, as described in Methods.

ahead of the 2,5-diketocamphane 1,2-monooxygenase. This latter enzyme migrated as two adjacent protein bands as reported previously (Yu \& Gunsalus, 1969; Taylor \& Trudgill, 1986). SDS-PAGE gave a single protein band for each enzyme on gels ranging from 11 to $15 \%$ acrylamide (Fig. 4). A small difference in $M_{\mathrm{r}}$ was apparent and, by reference to the marker proteins, the 3,6-diketocamphane 1,6-monooxygenase subunit has an $M_{\mathrm{r}}$ of $40300 \pm 800$ (average of 3 runs), some $3000-4000$ smaller than the subunit of the 2,5-diketocamphane 1,2monooxygenase.

\section{(iii) $p I$ values}

Isoelectric focussing gave a pI value of $5 \cdot 5$ for the 3,6diketocamphane 1,6-monooxygenase while the value for 2,5-diketocamphane 1,2-monooxygenase was lower at $4 \cdot 6$.

(iv) $M_{r}$ of native 3,6-diketocamphane 1,6-monooxygenase The $M_{\mathrm{r}}$ of the native enzyme was determined to be 76000 by ultracentrifugal analysis from Yphantis (1964) plots 
of results taken from four separate sets of plate readings. This value too was smaller than the 78000 reported for the 2,5-diketocamphane 1,2-monooxygenase (Taylor \& Trudgill, 1986).

\section{3,6-Diketocamphane 1,6-monooxygenase; electron donors and electron carriers}

The purified enzyme exhibited a $\lambda_{\max }$ at $282 \mathrm{~nm}$ and no evidence for the presence of any remaining flavin prosthetic group. The active oxygenating complex was reconstituted by the addition of FMN but FAD was ineffective. The oxygenase was inactive with $(+)$-camphor. Unfortunately neither 2,5- nor 3,6-diketocamphane was available for testing as an alternative substrate.

The purified NADH dehydrogenase from (+)-camphor-grown cells was an efficient electron donor and dictated the absolute specificity of the reconstituted complex for NADH.

Previous suggestions that the same soluble NADH dehydrogenase is synthesized irrespective of the camphor isomer used as carbon source (Gunsalus et al., 1965) are supported by these studies. Similar induced levels of NADH dehydrogenase were found in crude extracts of $(+)$ - and (-)-camphor-grown cells. Closely similar behaviour during $\left(\mathrm{NH}_{4}\right)_{2} \mathrm{SO}_{4}$ fractionation and DEAEcellulose chromatography, and identical elution patterns when enzyme from either source was subjected to FPLC on the Mono $Q$ column all suggest that a common dehydrogenase serves to provide electrons to either 2,5or 3,6-diketocamphane monooxygenase.

\section{Immunological studies}

\section{(i) Immunodiffusion}

In immunodiffusion experiments on Ouchterlony plates antibodies raised against purified 3,6-diketocamphane 1,6-monooxygenase gave fairly weak precipitin bands with the 3,6-diketocamphane oxygenase but, although a range of combinations of antibody and 2,5-diketocamphane monooxygenase was used, no precipitin bands were seen at any time with the latter enzyme.

\section{(ii) ELISA}

Interaction of the antibody with the two enzyme proteins was then explored in a more quantitative manner by ELISA. In a typical assay, PVC wells were coated with $2 \mu \mathrm{g}$ antigen (3,6-diketocamphane monooxygenase or 2,5-diketocamphane monooxygenase), drained, washed with PBS followed by addition of $50 \mu \mathrm{l}$ of control (preimmune) serum, immune serum or partially purified antibody, over a dilution range from $10^{1}$ to $>10^{4}$. Wells were again drained, washed, $200 \mu 1$ of a $10^{3}$ dilution of the goat anti-rabbit alkaline phosphatase conjugate added, incubated for $2 \mathrm{~h}$, drained, washed and substrate added. Reactions were stopped after $30 \mathrm{~min}$ at $37^{\circ} \mathrm{C}$ and the $A_{405}$ of each well measured against the appropriate control. Control absorbance values did not exceed 0.01 . The interaction of antibodies raised against 3,6-diketocamphane monooxygenase was almost identical with both antigens over the concentration range investigated.

\section{(iii) Western blotting}

Immunoblotting analysis was performed for two reasons: first, to confirm the close relationship between the two enantiomeric isofunctional enzymes, that was suggested on the basis of subunit size, holoenzyme structure, flavin specificity and use of a common NADH dehydrogenase; and second, to establish whether or not the two electrophoretically distinct forms of 2,5-diketocamphane monooxygenase both cross-reacted with the antibody. Accordingly, immunoblotting analysis was performed with both enzymes run on native and SDS-polyacrylamide gels. Dilutions of partially purified antibody in excess of $10^{3}$ were necessary to supress non-specific background reaction and under these conditions the 3,6diketocamphane monooxygenase, the two bands of the 2,5-diketocamphane 1,2-monooxygenase (native gels) and the subunit band of each enzyme (SDS gels) all cross-reacted with the antibody. Results for an SDS gel are shown in Fig. 4.

\section{(iv) Enzyme induction patterns}

Although we decided to adopt a 'single isomer' approach to cell growth for enzyme isolation in that each enzyme was initially isolated from cells grown on the respective camphor enantiomer, the whole cell oxidation studies suggested a less discriminatory situation; cells grown on either isomer of camphor being capable of the immediate rapid oxidation of both. Cultures were grown on $(+)-$ and $95 \%$ pure (-)-camphor as described in Methods. Equal quantities of cells were disrupted and, following centrifugation, equal amounts of protein were subjected to chromatography on separate indentical DEAEcellulose columns. Fractions from both columns were assayed for 2,5-diketocamphane monooxygenase and 3,6-diketocamphane monooxygenase, and active fractions pooled. Pool volumes were measured and a sample from each assayed for its respective monooxygenase in the presence of excess NADH dehydrogenase and an optimum amount of FMN. Because of the number of steps involved and the difficulties of optimizing assays it was difficult to obtain precise values for oxygenase component activity. However, the results shown for the partially purified enzymes in Table 2 clearly demonstrated the induction of both monooxygenases irrespective of the camphor isomer used for 
Table 2. Activities of 2,5-diketocamphane and 3,6diketocamphane monooxygenases obtained by DEAEcellulose chromatography of extracts of $(+)$ - and (-)camphor-grown P. putida ATCC 17453

Crude cell extracts ( $4 \mathrm{~g}$ protein) obtained from cells grown on $(+)$ or (-)-camphor were subjected to DEAE-cellulose chromatography on separate columns $(20 \times 2.5 \mathrm{~cm})$ which were washed with $300 \mathrm{ml} 21 \mathrm{~mm}$-phosphate buffer ( $\mathrm{pH} 7 \cdot 1)$ and developed with a linear gradient from 0 to $0.4 \mathrm{M}-\mathrm{KCl}$ in $600 \mathrm{ml}$ of the same buffer. Fractions of $6 \mathrm{ml}$ were collected, 2,5- and 3,6-diketocamphane monooxygenases assayed, pooled separately, and each pool assayed in the presence of NADH dehydrogenase (1.6 U) and FMN $(1 \cdot 5-4 \mu \mathrm{M})$.

\begin{tabular}{lcccc}
\hline \hline $\begin{array}{l}\text { Growth } \\
\text { substrate }\end{array}$ & Enzyme & $\begin{array}{c}\text { Volume } \\
\text { pooled } \\
(\mathrm{ml})\end{array}$ & $\begin{array}{c}\text { Total } \\
\text { activity } \\
(\mathrm{U})\end{array}$ & $\begin{array}{c}\text { Activity } \\
\text { ratio }\end{array}$ \\
\hline (+)-Camphor & $\begin{array}{c}\text { 2,5-diketocamphane } \\
\text { monooxygenase }\end{array}$ & $21 \cdot 9$ & $29 \cdot 6$ & \\
(+)-Camphor & $\begin{array}{c}\text { 3,6-diketocamphane } \\
\text { monooxygenase }\end{array}$ & $36 \cdot 5$ & $8 \cdot 4$ & $3 \cdot 5: 1$ \\
(-)-Camphor & $\begin{array}{c}\text { 2,5-diketocamphane } \\
\text { monooxygenase }\end{array}$ & $30 \cdot 0$ & $54 \cdot 3$ & \\
(-)-Camphor & $\begin{array}{c}\text { 3,6-diketocamphane } \\
\text { monooxygenase }\end{array}$ & 36.0 & $15 \cdot 9$ & $3 \cdot 4: 1$ \\
\hline \hline
\end{tabular}

growth. Neither enzyme was detectable when extract of succinate-grown cells was similarly processed.

\section{Discussion}

Growth of $P$. putida ATCC 17453 on (-)-camphor, followed by $\left(\mathrm{NH}_{4}\right)_{2} \mathrm{SO}_{4}$ fractionation of the resultant cell extract, confirmed the enantiomeric specificity of the Baeyer-Villiger monooxygenase induced by growth on this isomer. Although 3,6-diketocamphane was not available it is logical to presume that, as is the case for 2,5-diketocamphane 1,2-monooxygenase, a second keto group (in this case in the 3-position) is not a requirement and that the ability to distinguish 3,6-diketocamphane from the 2,5- derivative is conferred by the position of the carbonyl group adjacent to the most substituted bridgehead. The two enzymes are closely related in size and subunit structure. The holoenzymes can be distinguished by ion exchange purification procedures, reflecting their different $\mathrm{pI}$ values, and by non-denaturing PAGE. SDS-PAGE of the 3,6-diketocamphane 1,6monooxygenase demonstrated that it consists of two electrophoretically identical subunits which are about 3 $\mathrm{kDa}$ smaller than the pair from which the 2,5-diketocamphane monooxygenase is constructed (Taylor \& Trudgill, 1986). Given the difficulties of assay optimization, the specific activities of the pure proteins under identical assay conditions showed consistent differences (Table 1). The lower specific activity of the 3,6-diketocamphane 1,6-monooxygenase was also re- flected in relative recoveries of each enzyme although, paradoxically, (-)-camphor appeared to be the better inducer (Table 2). The two enzymes are very similar in other respects. Each binds flavin in a non-covalent manner; each apoenzyme is specifically reactivated by FMN and both can make use of the NADH dehydrogenase (EC 1.6.8.1) induced by growth with (+)-camphor as the electron donor. Similarly, the induction of an NADH dehydrogenase during growth on (-)camphor that can donate electrons to both oxygenases and behaves in an identical manner when subjected to FPLC on a Mono-Q column suggests that both oxygenases use a common NADH oxidase. It has been suggested that the weak association of 2,5-diketocamphane 1,2-monooxygenase and the NADH dehydrogenase is through the FMN, for which they both have affinity (Taylor \& Trudgill, 1986). 2,5-Diketocamphane 1,2-monooxygenase can be purified essentially with the FMN intact, by avoiding FPLC ion exchange columns but, as the NADH dehydrogenase has a rather weak binding affinity $\left(K_{\mathrm{D}} 4.5 \mu \mathrm{M}\right)$ for FMN (Trudgill et al., 1966), a link through the prosthetic group would explain the fragility of the oxygenating complexes formed by both the enantiomeric oxygenases with the NADH dehydrogenase.

Immunological investigations again stressed the close relationship between the two proteins. Ouchterlony double diffusion, immunoprecipitation experiments gave a weak single precipitin line with antibody and antigen under a variety of conditions. Failure to detect any precipitation with 2,5-diketocamphane 1,2-monooxygenase is puzzling since ELISAs showed no major differences in binding of antigen or 2,5-diketocamphane 1,2-monooxygenase to the antibody and, in the immunoblotting experiments, both native enzymes and the subunits bound the antibody.

Although these experiments have established some of the more fundamental characteristics of these two enantiomer-specific isofunctional biological BaeyerVilliger monooxygenases, a precise understanding of their evolutionary and structural relationship, and the significance of differences in overall charge and molecular mass which make them able to distinguish and select enantiomeric camphor molecules must await more detailed study, including sequence determination, subunit assembly and binding site structure.

We are grateful for the assistance of Dr Rodney Turner for his help in raising the antibodies and to Dr Aileen Smith for advice on antibody assay procedures.

\section{References}

Chapman, P. J., Cushman, D., Kuo, J.-F., Legall, J. \& Gunsalus, I. C. (1964). Pathways in microbial metabolism of camphor enantiomers. Proceedings of the American Chemical Society, 148th meeting. 
Conrad, H. E., Dubus, R. \& Gunsalus, I. C. (1961). An enzyme for cyclic ketone lactonization. Biochemical and Biophysical Research Communications 6, 293-297.

Conrad, H. E., Dubus, R., Namtvedt, M. J. \& Gunsalus, I. C. $(1965 a)$. Mixed function oxidation II. Separation and properties of the enzymes catalysing camphor lactonization. Journal of Biological Chemistry 240, 495-503.

ConRad, H. E., Lieb, K. \& Gunsalus, I. C. (1965b). Mixed function oxidation III. An electron transport complex in camphor lactonization. Journal of Biological Chemistry 240, 4029-4037.

Davies, B. (1964). Disc electrophoresis II. Method and application to human serum proteins. Annals of the New York Academy of Sciences 121, 404-427.

Gornall, A. G., Bardawill, C. J. \& David, M. M. (1949). Determination of serum proteins by means of the biuret reaction. Journal of Biological Chemistry 177, 751-766.

Gunsalus, I. C. \& Marshall, V.P. (1971). Monoterpene dissimilation: chemical and genetic models. CRC Critical Reviews in Microbiology 1, 291-310.

Gunsalus, I. C., Conrad, H. E., Trudgill, P. W. \& Jacobson, L. A. (1965). Regulation of catabolic metabolism. Israel Journal of Medical Sciences 1, 1099-1119.

LAEMMLI, U. K. (1970). Cleavage of structural proteins during the assembly of the head of the bacteriophage T4. Nature, London 227, 680-685.

Legall, J., Bertland, A. U., Namtvedt, M. J. \& Conrad, H. E. (1963). Enzymes and intermediates from D- and L-camphor induced Pseudomonads. Federation Proceedings 22, 295.

McKINNEY, M. M. \& PARKINSON, A. (1987). A simple non-chromatographic procedure to purify immunoglobulins from serum and ascites fluid. Journal of Immunological Methods 96, 271-278.

Mejbaum-Katzenellenbogen, W. \& Dobryszycka, W. M. (1959).
New method for quantitiative determination of serum proteins separated by paper electrophoresis. Clinica Chimica Acta 4, 515-522.

Ougham, H. J., TAYlor, D. G. \& Trudgill, P. W. (1983). Camphor revisited: the involvement of a unique monooxygenase in the metabolism of 2-oxo- $\Delta^{3}-4,5,5$-trimethylcyclopentenylacetic acid by Pseudomonas putida. Journal of Bacteriology 153, 140-152.

Palchaudhuri, S. \& Chakrabarty, A. M. (1976). Isolation of plasmid deoxyribonucleic acid from Pseudomonas putida. Journal of Bacterio$\log y$ 126, 410-416.

Pelter, A. \& Harper, S. H. (1969). Bicyclic monoterpenes and related compounds. In Rodd's Chemistry of the Carbon Compounds, vol. 2C, pp. 136-255. Edited by S. Coffey. Amsterdam: Elsevier.

Rheinwald, J. G., Chakrabarty, A. M. \& Gunsalus, I. C. (1973). A transmissible plasmid controlling camphor oxidation in Pseudomonas putida. Proceedings of the National Academy of Sciences of the United States of America 70, 885-889.

Rosenberger, R. F. \& ElSDEN, S. N. (1960). The yields of Streptococcus faecalis grown in continuous culture. Journal of General Microbiology 22, 726-739.

TAYlOR, D. G. \& TRudGill, P. W. (1986). Camphor revisited: studies of 2,5-diketocamphane 1,2-monooxygenase from Pseudomonas putida ATCC 17453. Journal of Bacteriology 165, 489-497.

Trudgill, P. W., Dubus, R. \& Gunsalus, I. C. (1966). Mixed function oxidation V. Flavin interaction with a reduced diphosphopyridine nucleotide dehydrogenase, one of the enzymes participating in camphor lactonization. Journal of Biological Chemistry 241, 194-205.

VESTERBERG, O. (1972). Isoelectric focussing of proteins in polyacrylamide gels. Biochimica et Biophysica Acta 257, 11-19.

YPHANTIS, D. A. (1964). Equilibrium centrifugation of dilute solutions. Biochemistry 3, 297-317.

Yu, C. A. \& Gunsalus, I. C. (1969). Monooxygenases. VII. Camphor ketolactonase I and the role of three protein components. Journal of Biological Chemistry 244, 6149-6152. 